\title{
Management of an Underground River to Overcome Water Scarcity in the Gunung Sewu Karst Area, Indonesia
}

\author{
Choirul Amin ${ }^{*}{ }^{1,2}$, Priyono ${ }^{1}$, Arif Jauhari ${ }^{3}$, Yuli Priyana ${ }^{1}$, Kuswaji Dwi Priyono ${ }^{1}$, Munawar Cholil ${ }^{1}$ \\ ${ }^{1}$ Faculty of Geography, Universitas Muhammadiyah Surakarta \\ ${ }^{2}$ Doctoral Programme, Faculty of Geography, Universitas Gadjah Mada \\ ${ }^{3}$ KMPA Giri Bahama, Faculty of Geography, Universitas Muhammadiyah Surakarta \\ * Corresponding author (email: Choirul.Amin@ums.ac.id)
}

Received: 23 September 2016 / Accepted: 15 July 2017 / Published: 15 July 2017

\begin{abstract}
Since people living in a karst area periodically face a crisis due to a lack of fresh water, it is necessary to re-evaluate the ability to use water resources. An appropriate and effective management is required to use available water resource sustainably. We describe a management process of exploring underground river in karst region as water resources. The activities completed included four phases, namely exploration, pre-lifting activities, the water lifting and post-lifting activities. The exploration phase included speleological surveys and data collection for the cave mouth using remote sensing instrument. The pre-lifting was done to prepare various requirements before the lifting process was completed. The water lifting phase consisted of the construction of an underground river dam, the installation of submersible pumps, the construction of reservoirs and the installation of piping to connect to the public hydrant. The post-lifting phase was mainly conducted to organise water distribution evenly. This management model was evidenced to successfully overcome drought in Pucung village by providing fresh water to the local community. Moreover, this model promoted residents' cost savings by reducing their expenses for buying water from IDR $50,000 / \mathrm{m}^{3}$ to IDR $3,500 /$ $\mathrm{m}^{3}$ (1,300 percent).
\end{abstract}

Keywords: Speleological survey, underground river, water management, drought, Gunung Sewu karst area, Indonesia.

\begin{abstract}
Abstrak. Pada umumnya penduduk yang tinggal di daerah karst secara berkala menghadapi krisis karenakekurangan airbersih, oleh karena itu perlu untukmengevaluasikembalikemampuan untuk menggunakan sumber air secara baik. Pengelolaan yang tepat dan efektif diperlukan untuk menggunakan sumber air yang tersedia secara berkelanjutan. Kami menggambarkan proses pengelolaan eksplorasi sungai bawah tanah di wilayah karst sebagai sumber air. Kegiatan yang diselesaikan meliputi empat tahap, yaitu eksplorasi, kegiatan pra pengangkatan air, kegiatan pengangkatan air dan pasca pengangkatan air. Tahap eksplorasi meliputi survei speleologi dan pengumpulan data mulut gua menggunakan instrumen penginderaan jauh. Pra pengangkatan dilakukan untuk mempersiapkan berbagai persyaratan sebelum proses pengangkatan selesai. Fase pengangkatan air terdiri dari pembangunan bendungan sungai bawah tanah, pemasangan pompa submersible, pembangunan reservoir dan pemasangan pipa untuk terhubung ke hidran publik. Tahap pakca pengangkatan air terutama dilakukan untuk mengatur distribusi air secara merata. Model pengelolaan ini terbukti berhasil mengatasi kekurangan air di Desa Pucung dengan memberikan air bersih kepada masyarakat setempat. Selain itu, model ini memberikan penghematan biaya warga dengan mengurangi biaya mereka untuk membeli air dari Rp 50.000 / m3 menjadi Rp 3.500 / m3 (1.300 persen).
\end{abstract}

Kata Kunci: survey speleology, sungai bawah tanah, pengelolaan air, kekeringan, kawasan karst Gunung Sewu, Indonesia.

\section{Introduction}

There is a growing concern about the capacity of urban and rural communities to manage current water shortages, and to preparefor the shortages that may accompany the predicted climate changes (Ivey et al., 2004). Water resources are renewable but the availability is varying and limited based 
on geomorphological unit, therefore, should be managed to ensure the sustainability for community (Anna, 1998; Anna et al., 2016; Priyana and Sigit, 2004). For water resource management at the regional level, where the effects of human activities are inclined to be neglected or underestimated, climate change might be used to justify continuing the overexploitation and depletion of water resources. As a result, environmental problems can occur naturally such as certain species invasion (Hartono et al., 2006) and may be exacerbated by human activities such as landuse changes (Hao et al., 2009; Noor, 1996). Especially, karst regions that are naturally arid, rocky, and limited of water availability (Srijono and Nadia, 2013). Therefore, the ability of prehistoric populations to use water resources in a sustainable way should be investigated since modern people periodically face hydro-related crises and droughts (Parise and Sammarco, 2015).

Pucung village is one of Karst landscapes in Indonesia that are characterized by a lack or scarce presence of surface water. Geographically, this is part of Gunung Sewu karst area in Eromoko, Wonogiri district. Marfai et al. (2013) explain that the Gunung Sewu karst region is a part of the Southern Mountains Zone in the western part of East Java. The Gunung Sewu karst region extends from Parang Endog Beach in Gunung Kidul Regency to Teleng Ria in Pacitan on the west coast.

Pucung village, like other villages in the Gunung Sewu karst area, always suffers from fresh water shortages, particularly for daily use (Figure 1). Several efforts have been made to solve the problem such as the establishment of a rain water tank and basin adjacent to the lake when the lake water was receding. However, those attempts were non-optimal since they were highly dependent on the natural conditions, and thus the water level was still low in the dry season. Even at the peak of the dry season, people in Pucung village have to queue to buy water from the water tank truck from Yogyakarta.
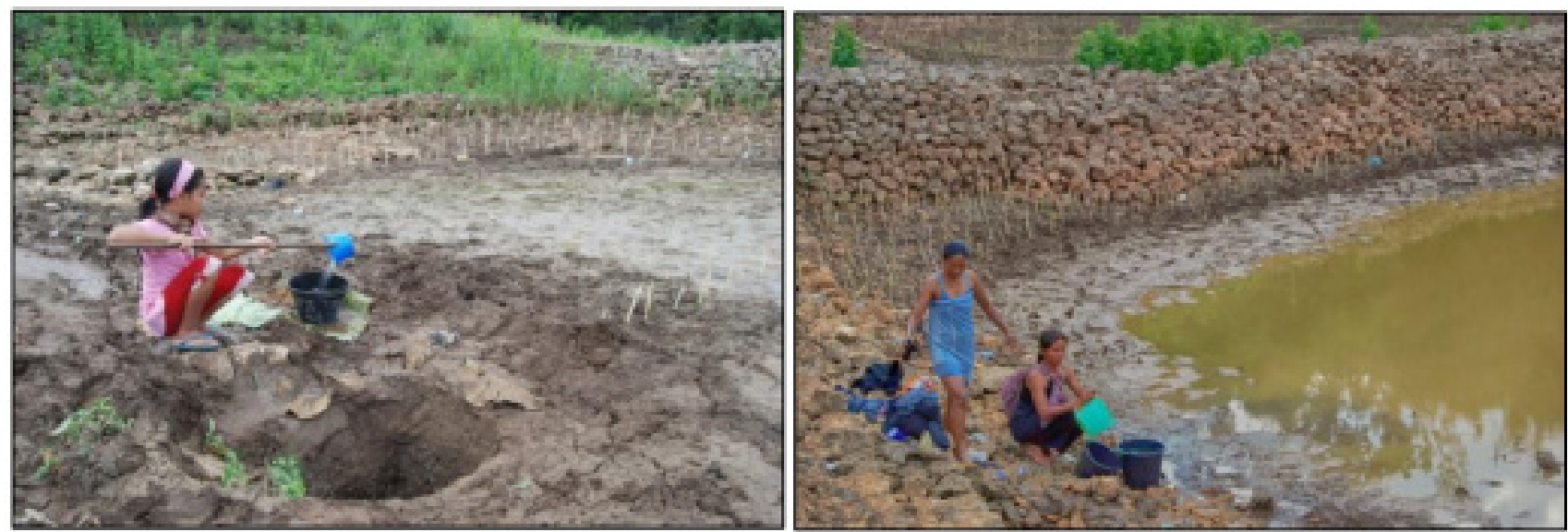

Figure 1. The drought conditions in Pucung village. Left: A child taking water from the basin at the edge of the pond for her family. Right: Daily activities such as bathing, washing and taking water occurred at the pond (author documentation, 2009).

Although drought took place at the surface level in the area, the karst area actually has potential water resources that are located beneath the surface in the form of an underground river. However, water from the underground river in the karst area is still rarely used by the community. This is due to the cost of lifting water from underground to the surface, which is relatively high. In addition, the terrain that must be traversed to reach the underground river is also very difficult. Therefore, the Faculty of Geography at the University of Muhammadiyah Surakarta (UMS) attempted to investigate the potential of underground water resources to meet the need for water for the residents of Pucung village.

Pucung village, with a population of 4,139 inhabitants, comprises 15 hamlets with a total area of $1,732.1$ ha, so the population density is 2.5 persons/ha. There are seven hamlets in Pucung 
village that always endure water shortages in the dry season, namely Turi, Kangkung, Brengkut, Pule, Gundi, Jalakan and Mijil, which have a total population of 1,940 people. The map of Pucung village is presented in Figure 2. The major source of livelihood in Pucung village is farming, while other residents work as civil servants, private employees, teachers, masons or carpenters. The average income per household is IDR 600,000 per month. Most of them still use wood at home for cooking and only few of them use gas, generally in the upper economic class.

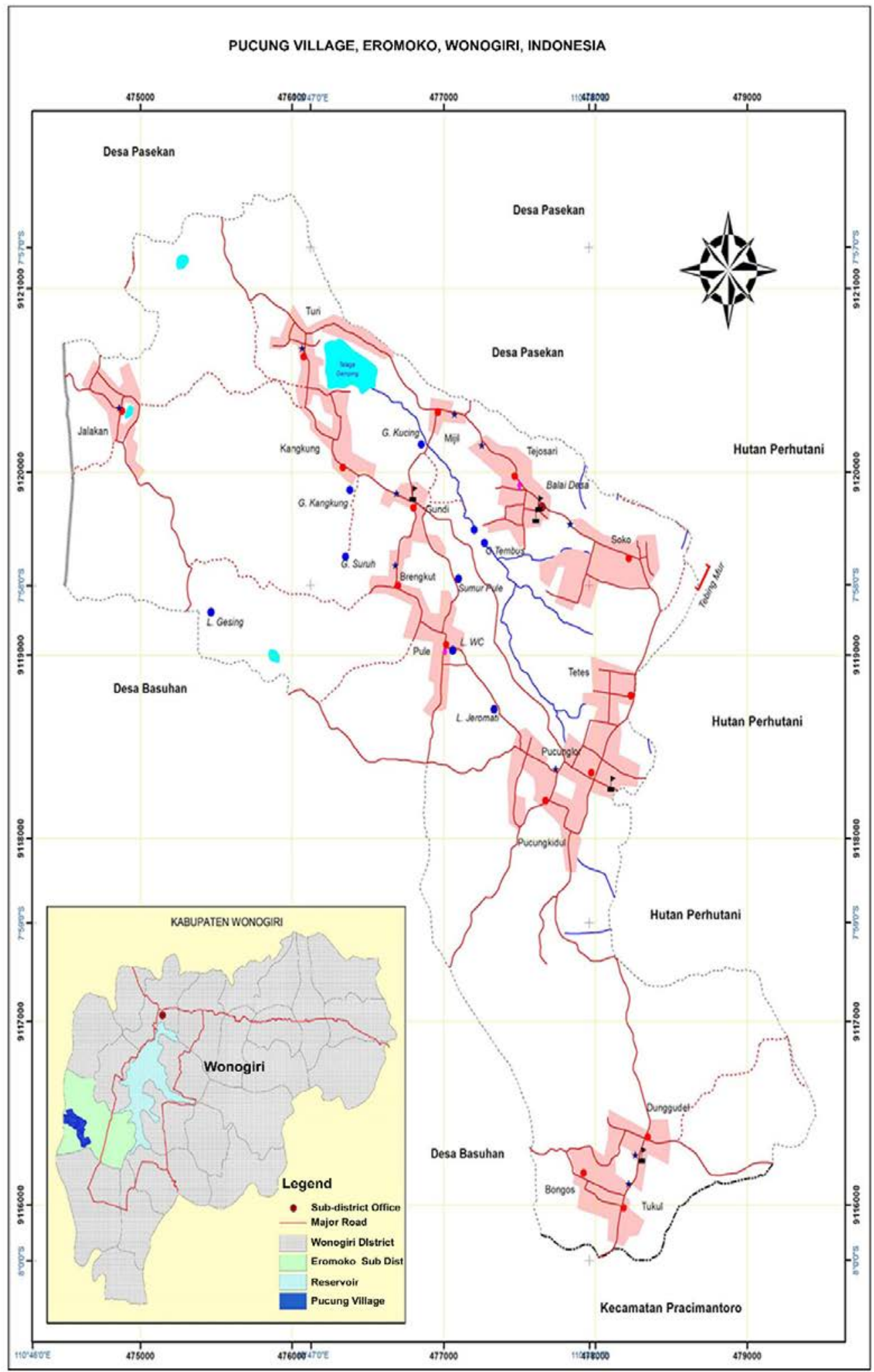

Figure 2. Location of Pucung village. 


\section{Pucung resid Ground Water Exploration}

One of the most common methods to investigate the presence of an underground river is the caving method. In this study, it was initiated by Keluarga Mahasiswa Pecinta Alam (KMPA) Giri Bahama and the Faculty of Geography UMS. Subsequently, the caving conducted by KMPA Giri Bahama was developed into a speleological survey. Various activities had been carried out in order to investigate the presence of the underground river in Pucung area, including the identification of the mouth of the cave, a cave survey, mapping the location of the cave and an underground-river-system survey.

A geographic information system (GIS) and speleological survey were the methods used to estimate the underground river system in Pucung village. The primary data used in this study is data from the interpretation of colour, infrared, aerial photos with a scale of 1:10,000 and field work (surface and subsurface survey). The aerial photo interpretation was employed to obtain a geological map, landform map, morphology map, drainage patterns map and cave distribution map. GIS was used to predict the underground river system through map overlays that had been produced previously.
The results show that there is an underground river system in Pucung village, for which the corridor was found in the Goa Suruh (Suruh Cave). The most potential underground water was found in the cave's corridor branches and the main stream of the underground river.

The use of geography equipment and methods played an important role in the exploration phase. The caving method was guided by satellite imagery and topographic maps, which made the survey run efficiently. The process eventually found an underground river at the corridor of Goa Suruh (Figure 3). It was the only cave that contained water. The distance between the mouth of Goa Suruh and the underground river was quite far, being approximately 300 metres. Moreover, the pathway for entry into the underground river was relatively difficult. About 30 metres from the mouth of the cave, the first hole was found, which could only be entered by three people. Subsequently, they needed to pass through a vertical corridor of 17 metres in length. The next corridor was a ramp and this was followed by a vertical corridor of about 11 metres in length, after which the underground river was reached.
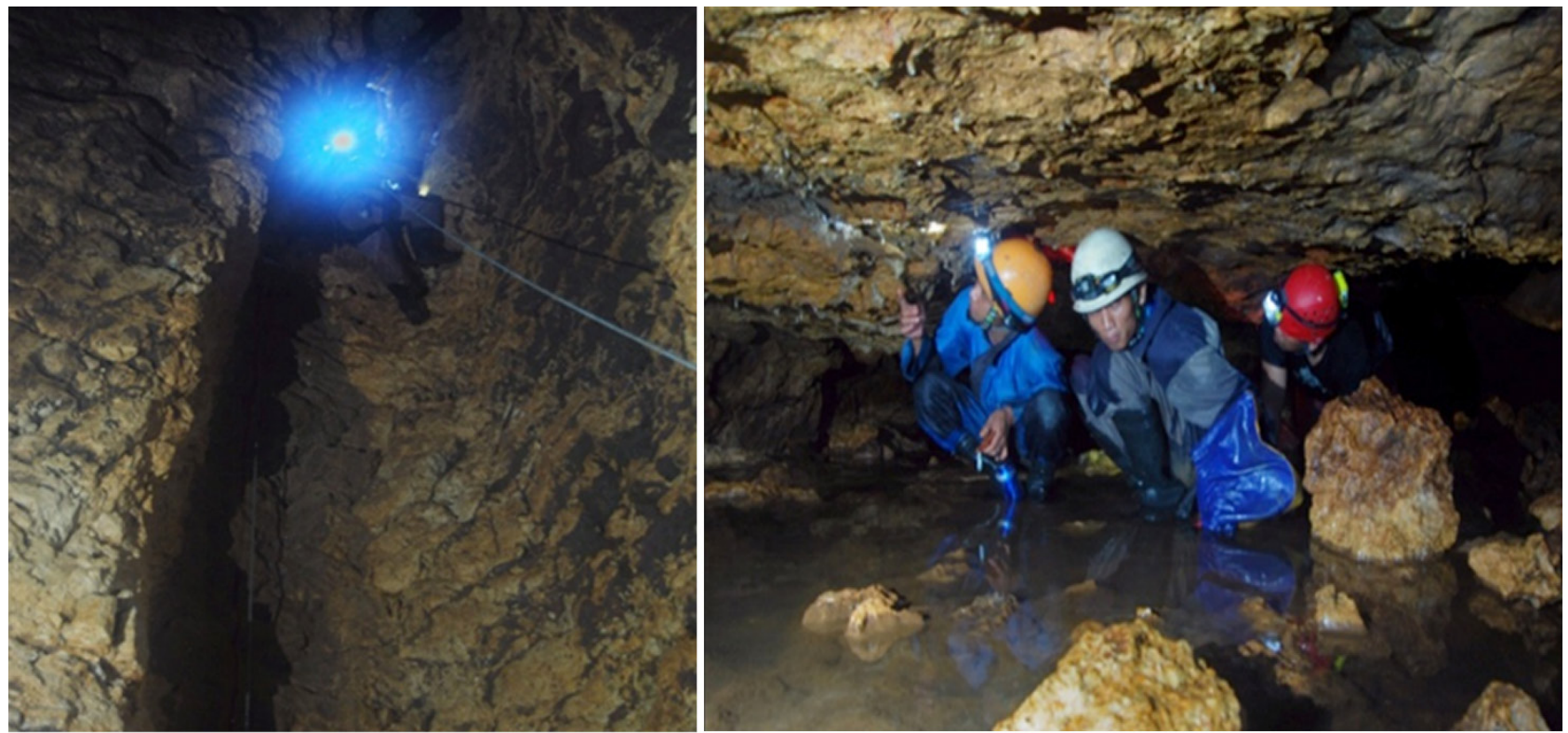

Figure 3. The discovery of the underground river in the corridor of Goa Suruh. Left image: vertical shaft to the underground river as high as 17 metres. Right picture: underground river of Goa Suruh (author documentation, 2000). 


\section{Pre-lifting of the Water}

Pre-lifting activities were carried out after the water in the Goa Suruh underground river was verified to be suitable for public consumption. Actually, various activities pertaining to the preparation for lifting the water from the underground river had been initiated since 2002. The activities included the measurement of the water quality and water debit, and the socialization, education and promotion of the use of the underground river among local community. Furthermore, lifting water from the Goa Suruh underground river to meet the water needs of the Pucung residents was also performed (Figure 4).

The water debit measurements showed that the discharge of the Goa Suruh underground river was at least 2 litres/sec with a constant flow throughout the year; thus, it could be estimated that the water would be available at the peak of the dry season. This water resource could potentially be lifted to meet the fresh water needs of the community in Pucung village, who often suffered from drought in the dry season.

From 2007-2010, information about the condition of the karst region was disseminated among the village government and the public through the media, a slide show and a movie. Socialization to assure the community of the existence of the underground river was equipped with images and videos. Moreover, Ashari, the head of Pucung village, also came inside the cave and proved the existence of the river himself.

In 2008, training on caving and the use of vertical equipment was conducted with the participants, including the local community and people who were interested in the underground river. In 2009, the mapping of Pucung village was carried out. From 2010-2012, fundraising was conducted to seek donors to finance the water lifting programme.
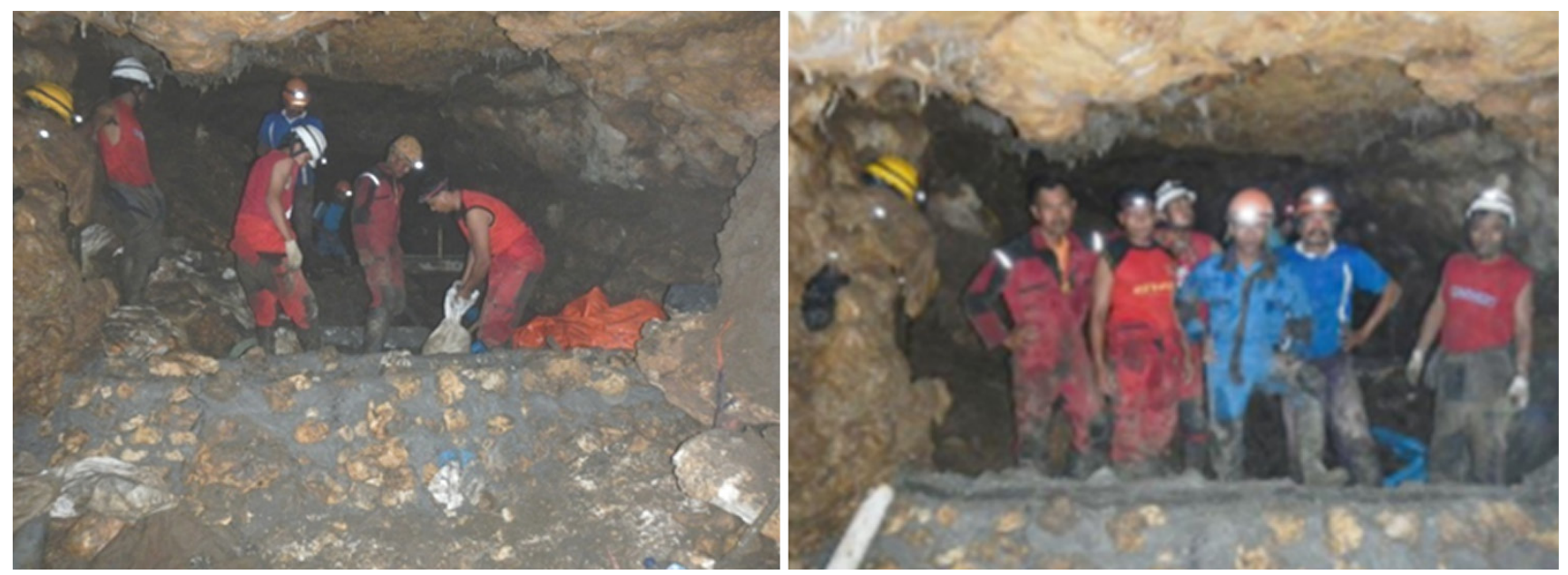

Figure 4. The construction of the underground river dam was done through gotong royong by the residents of Pucung village, and the members of KMPA Giri Bahama and the Faculty of Geography UMS (author documentation, 2012).

\section{The Lifting Process}

The members of the Faculty of Geography UMS and the members of KMPA Giri Bahama together with Pucung residents, local government, and Dewan Dakwah Islamiyah Indonesia (DDII) Central Java collaborated to implement the programme for lifting water from Goa Suruh. The programme included several steps, namely a pre-employment survey; underground river damming work; the installation of electricity, plumbing and water pumps; underground river water lifting; the manufacture of the tank; and building the road to Goa Suruh (Figure 5).

The cost of lifting the water was IDR 600 million, consisting of 35\% from the Faculty of Geography UMS, 25\% from DDII Central Java, $20 \%$ from Wonogiri local government and 20\% from Pucung society. The water lifting was successfully carried out in January 2013 and water distribution began in March 2013. 
This programme was performed to meet the water needs in addition to providing economic benefits for the local community. In 2012, the price of fresh water was IDR 200,000 per tank with a capacity of $4 \mathrm{~m}^{3}\left(\right.$ IDR $\left.50,000 / \mathrm{m}^{3}\right)$.
The lifting of water from the underground river suppressed the price of water to IDR $3,500 / \mathrm{m}^{3}$. Thus, the programme successfully provided a cost saving that amounted to 1,300\% (from IDR $50,000 / \mathrm{m}^{3}$ to IDR $\left.3,500 / \mathrm{m}^{3}\right)$.
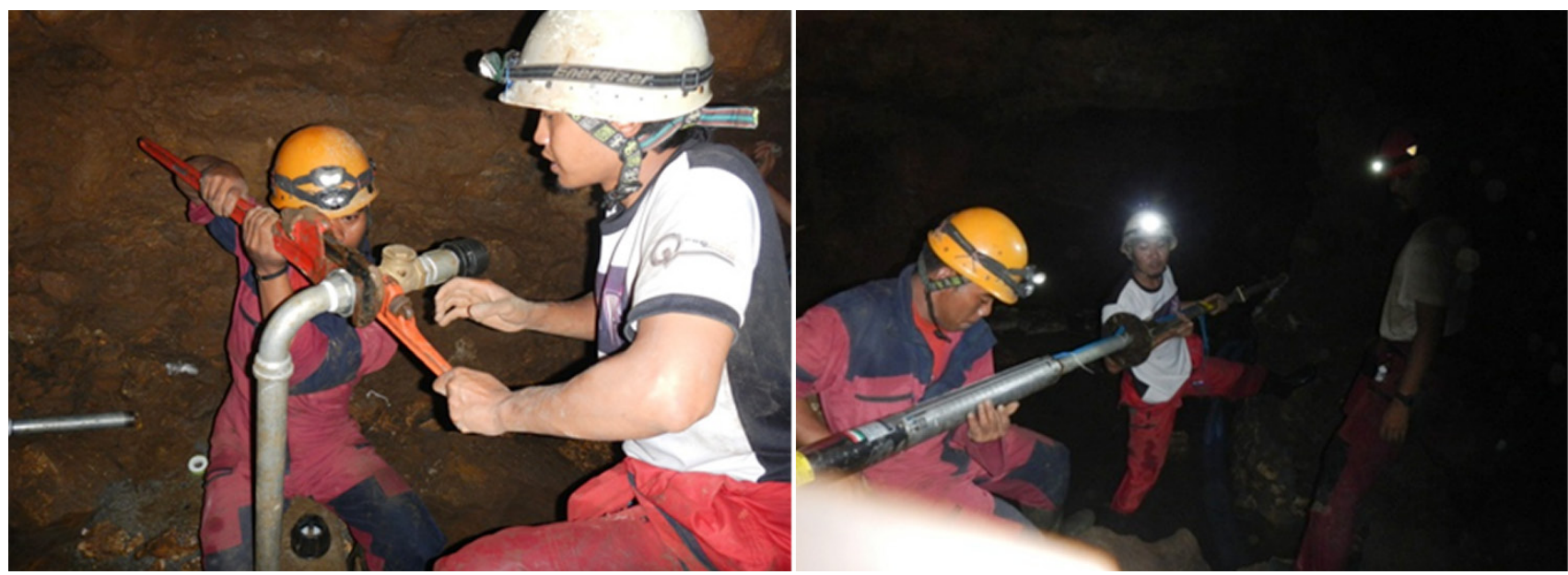

Figure 5. Left: Removing the 1.5 HP submersible pumps. Right: Mounting 2 HP submersible pumps in Goa Suruh (author documentation, June 2014).

\section{Post-lifting}

The distribution of water in Pucung village faced some problems. First, there was a low pumping discharge so that the availability of water for the population was still inadequate. Second, the distribution of water was uneven. Both of these constraints, however, triggered new social problems including jealousy among the population.

The problem was transformed in the form of revocation or destruction of pipes and opening the ball valve in order for the water to flow to a particular place, which was done by irresponsible people. The removal or destruction of pipes caused a loss to all parties since it hampered the distribution of water for the community and escalated the operational costs for the activity. In addition, the opening of the valves had caused suspicion among the population and disrupted the water distribution schedule. Shortly after this occurred, the constraints on the water distribution in Pucung village had caused social conflict.

The problem of the water shortage was solved by replacing the $1.5 \mathrm{HP}$ discharge pump with a $2 \mathrm{HP}$ discharge pump. The new pump increased the pumping discharge from 0.9 litres to 1.2 litres per second. The duration for charging stations with a tank capacity of 12,000 litres using the $1.5 \mathrm{HP}$ pump was 3 hours 42 minutes compared with the duration of 2 hours 47 minutes for the 2 HP pump. Thus, the increase in the capacity of the pump raised pumping-time efficiency.

Furthermore, the problem of uneven water distribution caused by the suboptimal management structure was solved by the establishment of community-based organization named "Tirta Goa Suruh". The PKM-M team from the Faculty of Geography UMS facilitated the establishment of this organization, ranging from the preparation of meetings, the election of the organization's committee and organizational management training to the installation and use of the tool for vertical work and the equipment maintenance. In addition, the PKM-M team of the Faculty of Geography UMS also trained the youth of Pucung village with respect to the vertical work equipment, in terms of its installation and utilization, to prepare the members of the youth as the next actors in Tirta Goa Suruh (Figure 6).

This community-based organization's motto is "Fresh water for a better life". This motto reflects the growing awareness of the 
importance of water availability for a better life. This awareness has encouraged a spirit of cooperation by promoting gotong royong to build better water resource management, especially considering that the amount of available water in the region was very limited. The existence of the Tirta Goa Suruh organization has meant water distribution is managed in a more fair and equitable way to prevent further social conflicts and resolve them beforehand.
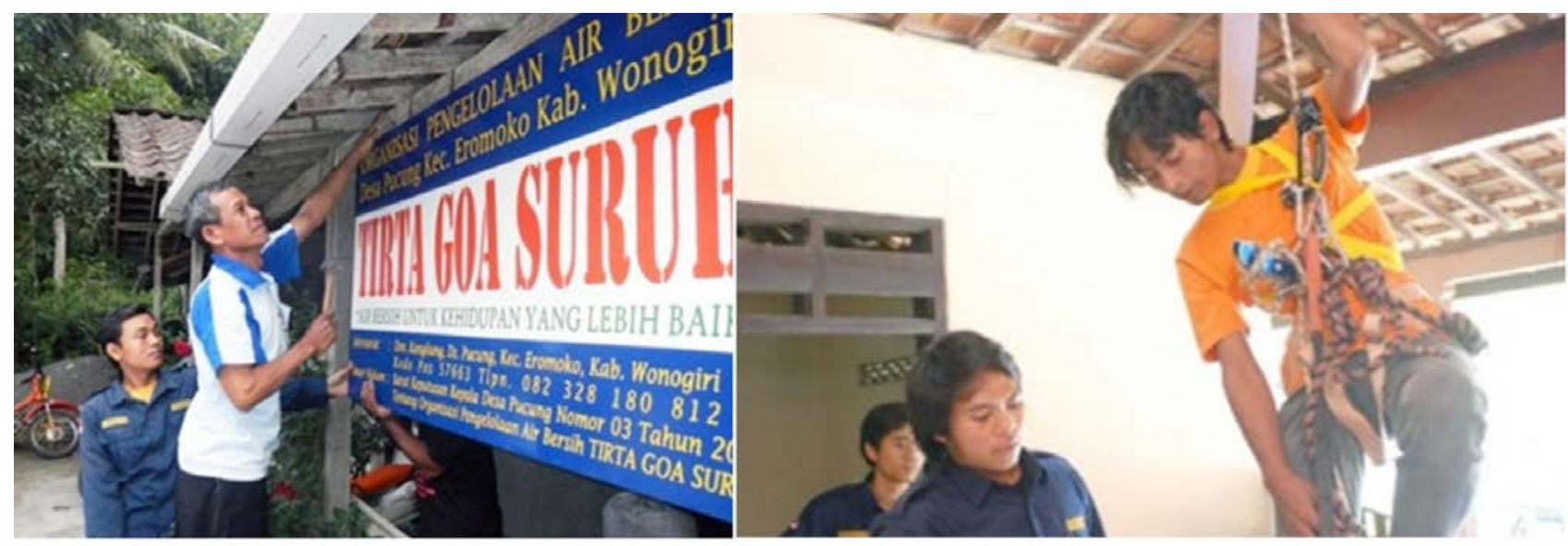

Figure 6. Left: The chairman of Tirta Goa Suruh setting up the sign for organization.Right: Vertical job training involving the youths in Pucung village (author documentation, 2014).

\section{Summary}

The model for underground water management included four phases of activity, namely (1) exploration and research, (2) prelifting activities, (3) the water lifting and (4) post-lifting activities. The exploration phase included speleological surveys and data collection for the cave mouth, springs and lakes. The water lifting from the underground river not only managed to solve the problem of water shortage, but also provided a cost saving of up to $1,300 \%$. To keep the flow of the water from the underground river throughout the year, it is necessary to carry out reforestation in the area adjacent to the underground river by planting trees, based on the land characteristics. To attain optimal utilization, the residents should expand the use of water. In addition to the use of water for agricultural and domestic purposes (drinking, bathing and washing), it can be expanded to include activities that increase family income, such as animal husbandry and other activities.

\section{References}

Anna, A. N., Priyono, K. D., Suharjo, S., \& Priyana, Y. (2016). Using Water Balance to Analyze Water Availability for Communities (A Case Study in Some Areas of Bengawan Solo Watershed). Forum Geografi, 30, 166-175. Retrieved from http://journals.ums.ac.id/index. $\mathrm{php} / \mathrm{fg} /$ article/view/2550

Anna, A. N. (1998). Role of Water Resources in Determining Spatial Planning of Region. Forum Geografi, 12. Retrieved from http://journals.ums.ac.id/index.php/fg/article/view/473

Hao, Y., Wang, Y., Zhu, Y., Lin, Y., Wen, J.-C. and Yeh, T.-C.J. (2009). Response of karst springs to climate change and anthropogenic activities: the Niangziguan Springs, China. Prog. Phys. Geogr., 33, 634-649. doi:10.1177/0309133309346651.

Hartono, H., Meteray, B. S. S., Farda, N. M., \& Kamal, M. (2006). Remote Sensing and GIS for Surface Water Resources in Rawa Biru-Torasi Merauke Papua. Forum Geografi, 20. Retrieved from http://journals.ums.ac.id/index.php/fg/article/view/1807

Ivey, J.L., Smithers, J., de Loë, R.C. and Kreutzwiser, R.D. (2004). Community capacity for adaptation to climate-induced water shortages: linking institutional complexity and local 
actors. Environ. Manage., 33, 36-47. doi:10.1007/s00267-003-0014-5.

Marfai, M.A., Cahyadi, A. and Anggraini, D.F. (2013). Typology, dynamics, and potential disaster in the coastal area district Karst Gunungkidul. Forum Geografi., 27, 147-158.

Noor, D. L. (1996). Analysis of Water Availability Model of Ngunut Sub-Watershed, Upper Bengawan Solo. Forum Geografi, 10. Retrieved from http://journals.ums.ac.id/index.php/ $\mathrm{fg} /$ article/view/507

Parise, M. and Sammarco, M. (2015). The historical use of water resources in karst. Environ. Earth Sci., 74, 143-152. doi:10.1007/s12665-014-3685-8.

Srijono, S., \& Nadia, N. (2013). Urang Cave Karst Environmental Development, as Tourism Object. Forum Geografi, 27, 99-110. Retrieved from http://journals.ums.ac.id/index.php/ $\mathrm{fg} /$ article/view/2369

Wu, C., Déry, S., Wu, W. (2015). A review of water resources utilization and protection in Southwest China. Sci. Cold Arid Reg., 7, 736-746.

Priyana, Y., \& Sigit, A. A. (2004). Groundwater Characteristic and Fresh Water Supplying System of the East Slope Merapi Volcano. Forum Geografi, 16. Retrieved from http://journals.ums. ac.id/index.php/fg/article/view/416 